\title{
BROMSULPHALEIN EXCRETION IN THE NEWBORN
}

\author{
BY
}

P. L. MOLLISON, M.D., M.R.C.P., and MARIE CUTBUSH, B.Sc.

(From the Medical Research Council, Blood Transfusion Research Unit, Department of Obstetrics, Postgraduate Medical School of London)

Ever since Yllpø published his valuable contribution to the subject of icterus neonatorum in 1913, it has seemed almost certain that the liver of the newborn infant is far less efficient than that of the adult in excreting bile pigment. Nevertheless very few direct studies of the excretory capacity of the liver of the newborn infant have been made, and the work reported here was carried out in the early part of 1947 under the impression that there were no previous studies of bromsulphalein excretion in the newborn. However, before the work was completed it was discovered that Herlitz had carried out bromsulphalein tests as long ago as 1926 and that more recently Salmon and Richman (1943) had worked on the problem. Our results were seen to be very similar to those of Herlitz, who found a definite impairment of excretion in the newborn, but in view of the fact that the findings of Salmon and Richman were altogether different it was felt worth while to complete the work and to present it.

\section{Methods}

Clinical material. Fourteen normal newborn infants were tested. Between one and five hours after birth the umbilical cord was cut across and, with careful aseptic precautions, a fine plastic catheter was passed up the umbilical vein for a distance of two to three inches. Bromsulphalein was then injected in a dose of $5 \mathrm{mg}$. per $\mathrm{kg}$. body weight made up in 0.5 per cent. solution; (in two out of the fourteen infants the dose was reduced to $3 \mathrm{mg}$. per kg.). The catheter was left in situ for periods up to two hours, and blood samples were obtained at various intervals after withdrawing 1 to $1 \frac{1}{2} \mathrm{ml}$. of blood through the catheter to rinse it. In some cases the carheter was withdrawn after the initial injection and a new catheter passed later to obtain the blood samples. The cord -was then tied in the ordinary way. Samples taken more than two hours after the injection were obtained from the external jugular vein or by pricking the warmed heel. The procedure did not appear to upset the infants in any way, and in no case was there any interference with the rapid, healthy scarring of the umbilicus.

The icteric indices of the cord blood and of blood samples taken at intervals during the following six days of life were also determined.

Ten normal adults were also tested; the object of this was twofold: firstly to obtain control material to compare with the findings in infants, in case our technique should yield slightly different results from those of other workers; secondly, to discover whether the withdrawal of samples through a plastic catheter through which bromsulphalein had been injected, would give falsely high results. To test this latter possibility, a catheter was introduced into an arm vein through a wide-bore needle and then passed up the vein for about 6 inches; bromsulphalein ( $5 \mathrm{mg}$. per $\mathrm{kg}$.) was injected and blood samples were withdrawn through this catheter. Simultaneously, blood samples were taken from the opposite arm by ordinary venepuncture.

Estimation of bromsulphalein. The bromsulphalein content of samples was measured in a photo-electric colorimeter using a green filter (0 gr. I, Chance). After adjusting the galvanometer reading to zero with diluted serum in the optical cell, one drop of 20 per cent. $\mathrm{NaOH}$ was added and the galvanometer deflection noted. A calibration curve was prepared by testing known dilutions of the injection solution. The relationship between bromsulphalein concentration and the extinction was almost linear with concentrations below $0.8 \mathrm{mg}$. per cent. Plasma samples' were suitably diluted with sodium sulphate before measurement, to bring their concentration below this level.

Many control tests were made to discover to what extent the optical density of normal plasma was altered by the addition of alkali. It was found that when testing undiluted plasma, differences as great as plus or minus 0.05 on the log scale might occasionally be produced, though with diluted plasma the deflections were smaller. Under the conditions of the test, this meant that amounts of the dye equivalent to less than $0.13 \mathrm{mg}$., that is to say 1.3 per cent. of the standard (see below), could not be detected with certainty. In the tabulation of results, amounts estimated as being less than 2 per cent. of the standard have therefore been described as 'nil'.

To conform with convention the results are expressed as percentages of a $10 \mathrm{mg}$. per cent. standard when using a $5 \mathrm{mg}$. per $\mathrm{kg}$. dose. In the two cases where a $3 \mathrm{mg}$. per $\mathrm{kg}$. dose was used the 
TABLE 1

PERCENTAGE RETENTION OF BROMSULPHALEIN AT INTERVALS AFTER INJECTION

\begin{tabular}{|c|c|c|c|c|c|c|c|c|}
\hline & & $\begin{array}{c}5-8 \\
\text { minutes }\end{array}$ & $\begin{array}{c}15-17 \\
\text { minutes }\end{array}$ & $\begin{array}{c}30-40 \\
\text { minutes }\end{array}$ & $\begin{array}{l}55-70 \\
\text { minutes }\end{array}$ & $\begin{array}{c}2 \\
\text { hours }\end{array}$ & $\begin{array}{c}4-6 \frac{1}{2} \\
\text { hours }\end{array}$ & $\begin{array}{l}24 \\
\text { hours }\end{array}$ \\
\hline \multirow[t]{2}{*}{$\begin{array}{l}\text { A. } 12 \text { infants receiving a dose of } \\
5 \mathrm{mg} . / \mathrm{kg} . ; \\
\text { standard }=10 \mathrm{mg} . \%\end{array}$} & $\begin{array}{r}1 \\
2 \\
3 \\
4 \\
5 \\
6 \\
7 \\
8 \\
9 \\
10 \\
11 \\
12\end{array}$ & $\begin{array}{r}58 \\
35 \\
64 \\
66 \\
57 \\
65 \\
53 \\
49 \\
112 \\
85 \\
91\end{array}$ & $\begin{array}{l}- \\
- \\
36 \\
34 \\
40 \\
22 \\
19 \\
30 \\
41 \\
45\end{array}$ & $\begin{array}{l}26 \\
20 \\
20 \\
24 \\
.18 \\
12 \\
15 \\
16 \\
25 \\
\end{array}$ & $\begin{array}{l}\overline{19} \\
23 \\
18 \\
21 \\
- \\
- \\
- \\
- \\
-\end{array}$ & $\begin{array}{r}- \\
- \\
- \\
19 \\
15 \\
19 \\
10 \\
14 \\
9 \\
19 \\
-\end{array}$ & $\begin{array}{l}- \\
\overline{11} \\
\overline{15} \\
\overline{-} \\
- \\
\frac{}{14}\end{array}$ & $\begin{array}{l}- \\
- \\
2 \\
7 \\
2 \\
\frac{2}{\mathrm{Nil}} \\
2 \\
-\end{array}$ \\
\hline & Av. & $66 \cdot 8$ & $33 \cdot 4$ & $19 \cdot 6$ & $19 \cdot 4$ & $15 \cdot 0$ & $13 \cdot 3$ & $2 \cdot 5$ \\
\hline \multirow{2}{*}{$\begin{array}{l}\text { B. } 2 \text { infants receiving a dose of } \\
3 \mathrm{mg} . / \mathrm{kg} . ; \\
\text { standard }=6 \mathrm{mg} . \%\end{array}$} & $\begin{array}{l}13 \\
14\end{array}$ & $\begin{array}{l}43 \\
44\end{array}$ & - & $\begin{array}{l}13 \\
16\end{array}$ & - & $\begin{array}{r}8 \\
12\end{array}$ & & \\
\hline & & $\stackrel{5}{\text { minutes }}$ & ${ }_{\text {minutes }}^{15}$ & $\begin{array}{c}30 \\
\text { minutes }\end{array}$ & $\begin{array}{c}60 \\
\text { minutes }\end{array}$ & \multicolumn{3}{|c|}{ Type of subject } \\
\hline \multirow[t]{2}{*}{$\begin{array}{l}\text { C. } 10 \text { adults receiving a dose of } \\
5 \mathrm{mg} . / \mathrm{kg} . ; \\
\text { standard }=10 \mathrm{mg} .\end{array}$} & $\begin{array}{l}15 \\
16 \\
17 \\
18 \\
19 \\
20 \\
21 \\
22 \\
23 \\
24\end{array}$ & $\begin{array}{l}64 \\
51 \\
60 \\
75 \\
\overline{-} \\
51\end{array}$ & $\begin{array}{r}8 \\
10 \\
16 \\
31 \\
14 \\
19 \\
\end{array}$ & $\begin{array}{c}3 \\
\text { Nil } \\
\text { Nil } \\
4 \\
2 \\
7 \\
\cdot \text { Nil } \\
\\
12 \\
2 \\
4\end{array}$ & $\begin{array}{c}\text { Nil } \\
\text { Nil } \\
\text { Nil } \\
\text { Nil } \\
\text { Nil } \\
2 \\
\text { Nil } \\
\\
12 \\
\text { Nil } \\
2\end{array}$ & \multicolumn{3}{|c|}{$\begin{array}{l}\text { Healthy adult } \\
\text { Healthy adult } \\
\text { Healthy adult } \\
\text { Healthy adult } \\
\text { Healthy adult } \\
\text { Healthy adult } \\
\text { Recently delivered woman ; } \\
\text { convalescent from pneu- } \\
\text { monia } \\
\text { Recent caesarean section : } \\
\text { mild diarrhoea recently } \\
\text { Convalescent from herni- } \\
\text { otomy } \\
\text { Convalescent from herni- } \\
\text { otomy }\end{array}$} \\
\hline & Av. & $57 \cdot 0$ & $15 \cdot 6$ & $3 \cdot 8$ & - & & & \\
\hline
\end{tabular}

results :were referred to a $6 \mathrm{mg}$. per cent. standard. Although it is usual to use a $10 \mathrm{mg}$. per cent. standard for a $5 \mathrm{mg}$. per $\mathrm{kg}$. dose, it is clear that with a plasma volume of approximately $45 \mathrm{ml}$. per kg. (DeMarsh et al., 1942) the theoretical maximum value is in fact rather higher; doubtless this explains the finding in one of our infants of an initial concentration of $11.2 \mathrm{mg}$. per cent.

Determination of icteric index. The principle of Ernst and Forster (1924) was used. $50 \mathrm{c.mm}$. of serum was added to $0.2 \mathrm{ml}$. of acetone, mixed well, and centrifuged. The colour of the supernatant fluid was compared with that of standard solutions of potassium bichromate in small tubes of uniform bore. This crude method was used because it needed only very small amounts of blood and because we were only interested in detecting gross differences.

\section{Results}

The results in infants and adults are set out in table 1 and summarized in fig. 1." It will be noted that in the infants the amount of dye fell to about 20 per cent. of the standard in thirty to forty minutes but thereafter the rate of disappearance was very slow, so that the average retention in seven infants two hours after injection was 15 per cent. In a few cases samples were taken from infants twenty-four hours after the injection, and in several of these there was a strong suggestion that traces of dye were still present, though the method of estimation made it impossible to be certain of the interpretation of small galvanometer deflections. In two cases where samples were taken from the same infant at approximately thirty minutes, sixty minutes, and twenty-four hours the log of the percentage retention was plotted against time and it was noted 


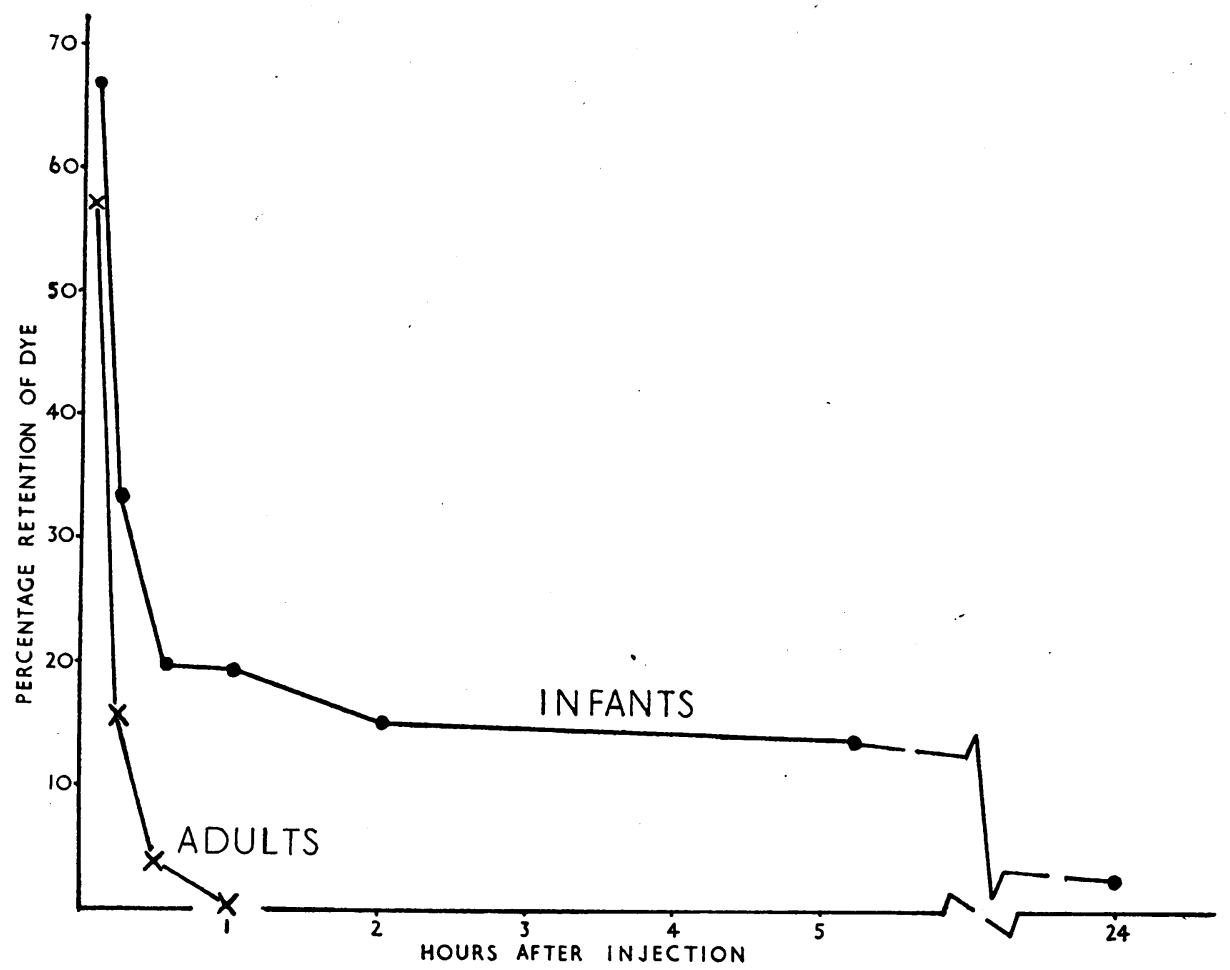

Fig. 1.-Bromsulphalein excretion in healthy infants and adults after a dose of $5 \mathrm{mg}$. per kg. of body weight 100 per cent. $=10 \mathrm{mg}$. per cent.

\begin{tabular}{|c|c|c|c|c|}
\hline \multirow[t]{2}{*}{ - } & \multirow{2}{*}{ Case No. } & \multicolumn{3}{|c|}{$\begin{array}{l}\text { Percentage of bromsulphalein } \\
\text { retained at : }\end{array}$} \\
\hline & & $\frac{1}{2}$ hour & 1 hour & 2 hours \\
\hline $\begin{array}{l}\text { A: group in which the icteric index was } 16 \text { or less three days } \\
\text { after birth } \ldots \\
.\end{array}$ & $\begin{array}{r}2 \\
6 \\
9 \\
10 \\
12 \\
14^{*}\end{array}$ & $\begin{array}{l}20 \\
18 \\
15 \\
16 \\
16\end{array}$ & $\begin{array}{l}\frac{19}{16} \\
- \\
-\end{array}$ & $\begin{array}{c}\overline{15} \\
14 \\
9 \\
14+ \\
12\end{array}$ \\
\hline $\begin{array}{l}\text { B: group in which the icteric index was } 32 \text { or more three days } \\
\text { after birth } \\
.\end{array}$ & $\begin{array}{c}1 \\
3 \\
4 \\
5 \\
7 \\
7 \\
8 \\
11 \\
13^{*}\end{array}$ & $\begin{array}{l}26 \\
\frac{20}{24} \\
\frac{12}{12} \\
25 \\
13\end{array}$ & $\begin{array}{l}\overline{23} \\
18 \\
21 \\
= \\
=\end{array}$ & $\begin{array}{r}- \\
\overline{-} \\
19 \\
19 \\
10 \\
19 \\
8\end{array}$ \\
\hline
\end{tabular}

* These two ińfants received a dose of 3 mg. per kg., the rest received $5 \mathrm{mg}$. per kg.

+ This sample was taken four hours after injection. 
that the estimates fell upon straight lines. This suggests that the rate of disappearance of bromsulphalein, after the initial phase of rapid removal, is proportional to the concentration.

By contrast, in adults, only about 4 per cent. of the dye was left in the plasma thirty minutes after injection and only 1 per cent. or less was present at sixty minutes. However, one exceptional case (Case 16) still had 12 per cent. of the dye in the plasma after sixty minutes; this result is discussed below.

That the amount of dye found in the infants' plasma was not due to the method of obtaining the blood samples was shown by the results in those

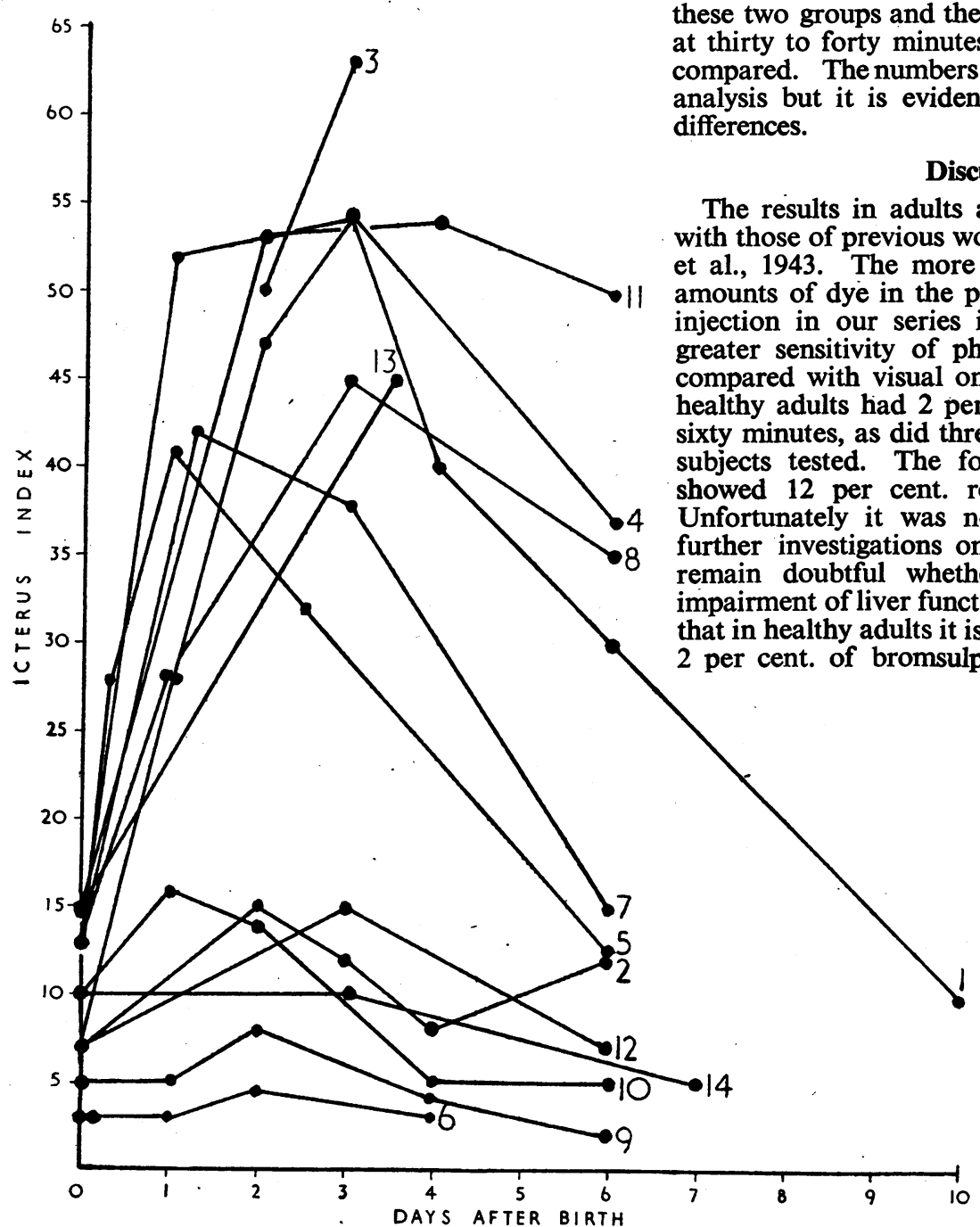

FIG. 2.-Observations of icteric index during the first few days of life in fourteen healthy infants whose bromsulphalein excretion during the first few hours of life was measured. adults in whom the samples were obtained through a catheter; in these, negligible differences were found between samples taken through the catheter and samples taken from the opposite arm. Moreover, a few samples taken from infants from the external jugular vein or from skin prick two to four hours after injection all contained amounts of the dye corresponding to between 10 and 20 per cent. of the standard. .

In fig. 2 the course of the icteric index changes in all the infants is plotted; it will be seen that the cases conveniently fall into two groups, namely those whose icteric index was 16 or lower on the third day of life and those whose index at the same time was 32 or higher. In table 2 the cases are divided into these two groups and the bromsulphalein retention at thirty to forty minutes and one to two hours is the numbers are too small for statistical analysis but it is evident that there are no gross

\section{Discussion}

adults are in essential agreement workers, for example Mateer frequent finding of small is is presumably due to the photo-electric measurements cent. or less retention at ree of the four convalescent retention at sixty minutes. was not possible to make any this patient and it must tion. In any case it is clear that in healthy adults it is unusual to find more than phalein retained one hour mg. per kg.

By contrast, in newborn infants receiving the same dose there was an average retention of 15 per cent. of the dye two hours after injection. This result unequivocally supports the contention of Herlitz that bromsulphalein excretion is greatly delayed in the newborn. Herlitz used a dose of $2 \mathrm{mg}$. per $\mathrm{kg}$. and found 20 to 30 per cent. retention of the dye at thirty minutes in the five infants which he tested within twenty-four hours of birth. This agrees fairly well with our figures of 12 to 26 per cent. 
retention at thirty to forty minutes in nine infants receiving a $5 \mathrm{mg}$. per $\mathrm{kg}$. dose and with our finding of 13 and 16 per cent. retention at thirty minutes in two infants receiving a $3 \mathrm{mg}$. per $\mathrm{kg}$. dose; in both the latter infants there was an appreciable amount of dye (8 and 12 per cent.) at two hours after injection. Neither our results nor those of Herlitz can be reconciled with those of Salmon and Richman (1943) who reported the rapid complete elimination of bromsulphalein within about twenty minutes of injecting a dose of $2 \mathrm{mg}$. per $\mathrm{kg}$. into infants from one to eight days old. Possibly the use of a visual method may have prevented the detection of relatively small amounts of dye.

It is of interest that Aballi and Castellanos (1925) carried out tests in infants one to two days old with phenoltetrachlorphthalein and found some retention of the dye sixty minutes after injection, whereas in infants aged two years or more there was no retention.

Our results add to the findings of Herlitz by demonstrating that the clearance of bromsulphalein from the plasma in the newborn is still incomplete five hours after injection and, in some cases, is still incomplete twenty-four hours after injection. They also agree with those of Herlitz in demonstrating no appreciable difference in bromsulphalein retention between those infants who develop jaundice and those who do not.

In the presence of hyperbilirubinaemia, a delayed excretion of bromsulphalein must be interpreted cautiously. Dragstedt and Mills (1936) have shown that after the injection of bilirubin into animals with normal liver function the excretion of bromsulphalein is delayed. Since the infant's plasma at birth contains on the average about $1.7 \mathrm{mg}$. per cent. of bilirubin (Davidson et al., 1941), some three times the average adult level, it might be contended that the infant's liver at birth is already occupied in excreting bilirubin to such an extent that an impaired excretion of bromsulphalein would be expected. However, this explanation will scarcely do for those two of our infants who had icteric indices in the cord blood of 5 or less and who subsequently showed no appreciable rise. These infants must have had bilirubin values well within the normal adult range (their plasma was almost colourless), and in them the diminished bromsulphalein excretion must be otherwise explained. Herlitz considered that an immaturity of the reticulo-endothelial system in the newborn was the explanation, but it seems to us more likely that the cause lies in an immaturity of the excretory function of the newborn liver. It has long been known that the ability of the newborn infant to excrete bile pigment is low (Yllpø, 1913; Snelling, 1933), and it seems extremely likely that the poor excretion of bromsulphalein is a reflection of this.

In adults, bromsulphalein is removed from the bloodstream in two phases, an early very rapid phase and a second slower phase. There is some evidence that the first of these two phases is due to the removal of dye by the R-E system whereas the second depends upon the excretory capacity of the liver (Wirts and Cantarow, 1942). It will be noted that in the infants studied the initial phase of removal was only slightly less rapid than in adults but that the second phase was strikingly slower. It seems probable, therefore, that the difference between the rate of removal of bromsulphalein in adults and newborn infants is due to a lower excretory capacity of the liver in the infant.

\section{Summary}

1. Bromsulphalein injected into infants a few hours after birth is removed from the plasma far less rapidly than in adults.

2. This finding is most probably to be explained by an immaturity of the excretory function of the liver in the newborn.

\section{REFERENCES}

Aballi, A. A., and Castellanos, A. (1925). Arch. Latino-americanos de pediatria, 19, 893.

Davidson. L. T., Merritt, K. K., and Weech, A. A. (1941). Amer. J. Dis. Child., 61, 958.

DeMarsh, Q. B., Windle, W. F., and Alt, H. L. (1942). Ibid., 63, 1123

Dragstedt, C. A., and Mills, M. A. (1936). Proc. Soc. exp. Biol. N.Y., 34, 467.

Ernst, Z., and Förster, J. (1924). Klin. Wschr. 3, 2326.

Herlitz, C. W. (1926). Acta paediatn., Stockh. 6, 214.

Mateer, J. G., Baltz, J. I., Marion, D. F., and MacMillan, J. M. (1943). J. Amer. med. Ass., 121, 723.

Salmon, G. W., and Richman, E. E. (1943). J. Pediat., 23, 522 .

Wirts, C. W., and Cantarow, A. (1942), Amer. J. dig. Dis., 9, 101.

Yllpø, A. (1913). Z. Kinderheilk., 9, 208. 